\title{
PERLINDUNGAN HUKUM TERHADAP ANAK DI BAWAH UMUR SEBAGAI PENGEMIS
}

\author{
I Wayan Edy Darmayasa, Anak Agung Sagung Laksmi Dewi, I Made Minggu Widyantara \\ Fakultas Ilmu Hukum Universitas Warmadewa, Denpasar - Bali, Indonesia \\ edydarmayasaa98@gmail.com, laksmiidewi29@gmail.com, mademinggu21@gmail.com
}

\begin{abstract}
Abstrak
Anak bukanlah objek perilaku menyimpang ataupun perbuatan tak manusiawi dari siapapun. Namun realitanya perlakuan eksploitasi anak di Indonesia telah menjadi suatu masalah yang kompleks. Penelitian ini dilakukan dengan tujuan mendeskripsikan bagaimana pengaturan hukum terhadap anak sebagai pengemis dan bagaimana perlindungan hukum terhadap anak di bawah umur sebagai pengemis. Penelitian ini menggunakan metode penelitian hukum normatif serta pendekatan perundang-undangan dan konseptual. Hasil penelitian ini menunjukkan bahwa pengaturan terhadap anak di bawah umur sebagai pengemis terdapat dan termuat dalam Pasal 2 ayat 1 Undang-Undang Kesejahteraan Anak No. 4 Tahun 1979 yang menjelaskan bahwa hak atas perawatan bimbingan asuhan kesejahteraan serta pembimbingan dengan kasih sayang merupakan hak anak begitu juga terkait pengasuhan tumbuh kembang anak dalam keluarga sehat dan baik. Selain itu, perlindungan hukum terhadap anak di bawah umur sebagai pengemis sebagaimana termuat dalam Undang-Undang Perlindungan Anak No. 35 Tahun 2014 Jo Undang-Undang No 23 Tahun 2002 dapat berupa pelayanan kesehatan sosial ekonomi serta pendidikan yang memadai.
\end{abstract}

Kata Kunci: Anak Di Bawah Umur, Pengemis, Perlindungan Hukum

\begin{abstract}
Children are not objects of deviant behavior or inhuman actions by anyone. However, in reality the child exploitation in Indonesia has become a complex problem. This research was conducted with the aim of describing the legal arrangements for children as beggars and the legal protection for minors as beggars. This study used a normative legal research method as well as statutory and conceptual approaches. The results of this study indicated that the regulation of minors as beggars is contained in Article 2 paragraph 1 of the Child Welfare Law No. 4 of 1979 which explains that the right to care for welfare care and guidance with affection is the right of the child as well as the care for the development of children in a healthy and good family. In addition, legal protection for minors as beggars as stipulated in the Child Protection Law No. 35 of 2014 in conjunction with Law No. 23 of 2002 can be in the form of socio-economic health services and adequate education.
\end{abstract}

Keywords: Underage Children, Beggar, Legal Protection

\section{PENDAHULUAN}

Hak anak untuk memperoleh pemeliharaan dan bantuan hingga pemeliharaan khususnya diberikan oleh keluarga selaku sentral pertumbuhannya serta kesejahteraannya dalam masyarakat lingkungannya. Pemberian bantuan maupun perlindungan untuk anak-anak sangat dibutuhkan dewasa ini sehingga dapat mengemban tanggung jawab dalam masyarakat. Dalam memperlakukan anak wajib dengan perilaku positif dan baik seperti dilihat dari aspek lingkungannya yaitu keluarga yang sehat dan bahagia penuh dengan rasa cinta kasih serta saling memahami. Dibesarkan dalam suasana damai tanpa tekanan atau kemerdekaan perlu dipersiapkan agar anak dapat menghadapi kehidupan dalam bermasyarakat (Prints, 1997).

Sebagai bentuk pendekatan guna melakukan perlindungan terhadap anak dapat dilakukan dengan memahami hak anak-anak Indonesia itu sendiri. Jadi, perlindungan terhadap hak-hak anak dapat tercapai dengan adanya keteraturan keadilan serta pertanggungjawaban. Oleh karena itu, 
peraturan hukum yang adil dan selaras diperlukan untuk perkembangan masyarakat secara keseluruhan.

Upaya perlindungan kenyataannya saat ini pemerintah masih belum mampu memberikan pengaruh maksimal begitu pula dengan aparat penegak hukum, masyarakat, dan pihak-pihak terkait lainnya yang berhak membantu. Melalui penjatuhan sanksi hukum seharusnya mampu memberikan keadilan namun sebaliknya seperti dalam penjatuhan hukuman kepada pelaku saat ini masih dianggap tidak adil atau tidak sesuai dengan akibat yang ditimbulkannya. Inilah bentuk ketidakadilan hukum yang dianggap dapat mengakibatkan jatuhnya masyarakat yang lemah (menjadi korban suatu kejahatan) agar diharuskan berurusan dalam dunia peradilan (Wahid \& Irfan, 2001).

Penjaminan kesejahteraan setiap warganya merupakan tanggung jawab setiap Negara tak terkecuali terkait perlindungan bagi setiap anak yang pada hakikatnya merupakan suatu bentuk hak asasi manusia (International Law Making, 2006; Said, 2018; Sudrajat, 2011). Anak dalam artiannya berdasarkan Undang-Undang Republik Indonesia Nomor 35 Tahun 2014 Tentang Perubahan Atas Undang-Undang Nomor 23 Tahun 2002 Tentang Perlindungan Anak bahwa merupakan pemberian Tuhan yang Maha Esa yang disebut sebagai amanah serta karunia dan harus dijaga hak yang melekat padanya harkat martabat dan hak-hak sebagai manusia lainnya serta haruslah dijunjung tinggi.

Setiap anak berhak atas kelangsungan hidup dalam hal berbangsa dan bernegara. Anak adalah masa depan bangsa serta generasi penerus cita-cita bangsa. Pada dasarnya setiap anak memiliki hak atas kelangsungan hidupnya. Dalam prakteknya bernegara dan berbangsa, anak dalam tumbuh dan kembangnya perlu perlindungan dari kekerasan hingga diskriminasi. Hak berpartisipasi dan kebebasan hak sipil merupakan sesuatu yang harus dijunjung dan dihargai pelaksanaannya. Bagi orang tuanya anak merupakan kebahagian dan memberikan arti yang mendalam. Konteks arti disini dimaksudkan dapat bernilai kepuasan isi bentuk kebanggaan dan rasa sempurna karena keturunan yang dapat dimiliki setiap orang tua sehingga diharapkan mampu melanjutkan setiap cita-cita hingga harapannya.

Fenomena eksploitasi terhadap anak yang menjadi korban semakin kompleks di Indonesia khususnya. Bukanlah pilihan yang menyenangkan untuk hidup sebagai korban eksploitasi. Menurut Bellamy, latar belakang keluarga yang miskin begitu juga pendidikan yang kurang atau terabaikan merupakan faktor penyebab eksploitasi anak terjadi. Oleh karena itu, anak terbiasa bekerja dengan cara tak terlatih begitu juga upah yang sangat rendah dan buruk nantinya mereka akan terjebak karena itu (Usman \& Nacorowi, 2004).

Salah satu bentuk masalah sosial terhadap anak saa ini adalah eksploitasi anak. Hal ini memang sewajibnya memerlukan pengawasan dan penindaklanjutan (Nihayah \& Legowo, 2016). Terlebih lagi, anak sebagai pengemis dalam kasus eksploitasi anak ini banyak terjadi dalam masyarakat, contohnya di Bali. Anak-anak sering terlihat di sekitaran Pasar Kumbasari Denpasar dan di sekitar jalan menuju pesisir pantai kuta. Pemanfaatan dan pemerasan tenaga kerja orang lain merupakan usaha eksploitasi terhadap anak yang melakukan pemanfaatan terhadapnya yang dilakukan oleh oknum kelompok atau individu baik untuk kepentingan sendiri atau kelompok.

Berdasarkan latar belang di atas, penelitian ini dilakukan dengan tujuan mendeskripsikan bagaimana pengaturan hukum terhadap anak sebagai pengemis dan bagaimana perlindungan hukum terhadap anak di bawah umur sebagai pengemis.

\section{METODE PENELITAN}

Metode penelitian yang digunakan dalam penyusunan materi penelitian ini adalah metode penelitian hukum normatif dengan merujuk pada pendekatan perundang-undangan serta konseptual. Ada beberapa sumber bahan hukum baik primer atau sekunder yang digunakan seperti KUHP hingga Undang-Undang Nomor 35 Tahun 2014 tentang Perubahan Atas Undang-Undang Nomor 23 tahun 2002 tentang Perlindungan Anak selain itu juga terdapat bahan hukum lainnya dari buku-buku ilmiah jurnal literature dan lain sebagainya. Data dikumpulkan dengan menggunakan metode kajian pustaka. Metode kualitatif digunakan untuk menganalisis data, dan data kemudian disajikan secara deskriptif.

\section{HASIL DAN PEMBAHASAN}

\section{Pengaturan Hukum terhadap Anak sebagai Pengemis}

Selain pernyataan para ahli, NAEYC (National Association Education for Young Children) mendefinisikan anak di bawah umur sebagai anak usia dini yang merupakan kelompok orang dalam 
rentang usia 0 hingga 8 tahun. Sekelompok orang atau manusia yang ada dalam suatu proses perkembangan serta pertumbuhan dikategorikan sebagai anak usia dini. Pada usia tersebut biasanya para pakar menyebutkan sebagai suatu periode emas (Golden Age) yang hanya dapat dialami satu kali untuk perkembangan kehidupannya. Pertumbuhan dan perkembangan anak usia dini perlu pengarahan secara fisik, bahasa, kognitif, kreativitas, dan sosioemosional yang sesuai dan seimbang serta diperlukan dalam upaya pertumbuhan dan perkembangan anak sebagai pondasi membangun suatu kepribadian yang utuh (Hartati, 2005).

Batasan usia serta pemahaman yang begitu beragam dan bermacam-macam bisa dilihat dari perbedaan sudut pandang yang digunakan dalam memaknai arti anak usia dini. Pemahaman tentang anak secara tradisional diidentikkan bagaikan manusia kecil yang dianggap masih polos belum dapat bertanggung jawab dan belum bisa apa-apa, dan dalam hal ini juga bisa dikategorikan belum mampu berfikir terang. Pemahaman lain tentang anak usia dini bahwa sebagai manusia yang kecil yang mana mempunyai potensi yang memerlukan pengembangan (Sukamti \& dkk, 2010).

Peraturan Pemerintah RI tentang Penanggulangan Gelandangan dan Pengemis Nomor 31 Tahun 1980 jika dilihat pada Pasal 1 ayat 2 dapat ditemukan pengertian dari pengemis yang mana disebutkan sebagai orang yang memiliki kehidupan dan penghidupan yang tidak layak dan tidak sesuai dalam suatu masyarakat serta dikategorikan sebagai tunawisma atau tidak memiliki tempat bernaung untuk tinggal hingga pekerjaan tetap, sehingga ia mengembara bebas di tempat umum tanpa tujuan jelas.

Secara umum mengemis dapat diartikan sebagai perilaku atau kegiatan meminta-minta untuk memperoleh penghasilan yang dilakukan di tempat umum dengan apapun alasan dan caranya dengan memengaruhi atau mengandalkan simpati orang lain terhadapnya. Dalam Kamus Besar Bahasa Indonesia kata mengemis/pengemis bukanlah suatu kata dasar dan memang tidak memilikinya, akan tetapi pengertiannya bisa dua yaitu meminta dengan merendahkan dirinya dan meminta-minta sedekah.

Cara-cara guna menarik simpati hingga belas kasih dari orang lain merupakan bentuk pola mengemis yang semakin dinamis guna mencapai sasarannya. Mengamen sambil mengemis, membawa anak saat mengemis, berpura-pura sakit, cacat, atau terluka hingga menenteng map minta sumbangan dapat dilakukan. Itu semua untuk menarik simpati orang lain untuk memberikan uang kepadanya jelaslah ini suatu pembohongan dan haram hukumnya.

Berbagai peraturan perundang-undangan contohnya dapat dirujuk pada keputusan presiden Nomor 36 Tahun 1990 sebagai bentuk ratifikasi dari konvensi PBB terkait Hak-hak yang dimiliki setiap Anak hingga Undang- Undang No. 30 Tahun 2014 Jo UU No. 23 Tahun 2002 tentang Perlindungan Anak Undang- Undang Kesejahteraan Anak. Pengaturan terhadap anak di bawah umur sebagai pengemis terdapat dan termuat juga dalam Pasal 2 ayat 1 Undang-Undang Kesejahteraan Anak No. 4 Tahun 1979 yang menjelaskan bahwa hak atas perawatan bimbingan asuhan kesejahteraan serta pembimbingan dengan kasih sayang merupakan hak anak begitu juga terkait pengasuhan tumbuh kembang anak dalam keluarga sehat dan baik.

\section{Perlindungan Hukum terhadap Anak di bawah Umur sebagai Pengemis}

Banyaknya persepsi terkait pengertian perlindungan hukum secara harfiah membuat bingung masyarakat. Untuk itu penguraian maknanya dalam ilmu hukum dan fenomena terkait diperlukan sehingga timbul istilah ini yang sangat membantu dalam mencari makna sesungguhnya dari perlindungan hukum itu. Istilah perlindungan hukum agar nantinya tidak menjadi multitafsir dan tidak ternodai prakteknya di masyarakat oleh oknum tak bertanggung jawab, maka dapat dirujuk sebagai upaya menegakkan hak serta kewajiban setiap masyarakat secara hukum atau di hadapan hukum itu sendiri, sehingga dapat dihindari dari pengaruh menyimpang yang ada.

Pengertian perlindungan hukum merupakan bentuk perlindungan bagi setiap subjek hukum itu sendiri yang mana perangkat yang digunakan bisa preventif atau upaya pencegahan dan represif atau upaya penegakkan. Ini juga bentuknya tertulis dan tidak tertulis. Dengan kata lain perlindungan hukum dapat dikatakan suatu konsep atau gambaran suatu fungsi hukum yang diharapkan mampu memberikan penjaminan terhadap ketertiban keadilan, kemanfaatan, serta ketentraman damai sejahtera.

Perlindungan Hukum terhadap anak merujuk pada Undang-undang Kesejahteraan Anak No 4 Tahun 1979 khususnya dalam pasal 2 ayat (3) dan juga (4) menentukan bahwa baik perlindungan hingga pemeliharaan terhadap anak semasih atau sudah dilahirkan. Setiap anak pada dasarnya 
memiliki hak atas itu semua yang mana dapat membahayakan dirinya baik menghambat perkembangan maupun pertumbuhannya dari sesuatu yang layak dan wajar didapatnya. Beberapa pengaturan tersebut dapat dijadikan dasar pemikiran bahwa upaya memperlakukan suatu keadaan yang adil dan benar adanya merupakan dasar bagi pemikiran mengenai kesejahteraan terhadap anak.

Peraturan Pemerintah Pengganti Undang-Undang (Perpu) tentang Perlindungan Anak Nomor 1 Tahun 2016 menegaskan pemberian Perlindungan hukum kepada anak sebagai upaya memberikan penjaminan perlindungan yang diberikan oleh Negara melalui pemerintah. Bukanlah masalah kecil jika menyangkut anak di dalamnya karena anak merupakan generasi penerus bangsa yang harus dijaga bagai asset hidup yang mampu menjadi harapan bangsa. Dalam hal menjadi korban pencabulan misalnya telah dilakukan upaya perlindungan hukum sedemikian rupa, seperti adanya pendampingan terhadap para korban hingga rehabilitasi atau pembinaan mental juga dilakukan untuk anak sebagai korban kejadian tersebut.

Pasal 13 Undang-Undang Perlindungan Anak Nomor 23 Tahun 2002 menyatakan bahwa hak dari setiap anak untuk mendapatkan pengasuhan yang sehat dan baik dengan kualitas yang baik pula wajib diberikan oleh setiap orang tak terkecuali keluarga melalui orang tua khususnya ataupun pihak lain seperti kerabat, masyarakat, wali, tempat pengasuhan, atau panti. Sehingga penjamin secara ekonomi sosial pendidikan hingga kesehatan dapat terbebas dari eksploitasi oleh oknum- oknum yang tak bertanggung jawab. Namun pada prakteknya masih terdapat kasus eksploitasi terhadap anak. Bentuk perlindungan yang mengkhusus kepada anak sebagai korban dari eksploitasi ini dapat merujuk pada ketentuan menurut Undang-Undang Nomor 23 Tahun 2002 pasal 59 yang menyatakan kewajiban pemerintah dalam bertanggung jawab melakukan perlindungan dan mencegah dari adanya eksploitasi anak.

Melihat peradaban bangsa dijadikan tolak ukur penerapan upaya perlindungan ini, perlu usaha ekstra dalam mewujudkan segala upaya tersebut sehingga hasil yang diperoleh maksimal pula. Setiap perbuatan hukum akan menimbulkan akibat hukum pula tak terkecuali dalam hal eksploitasi anak dan masalah perlindungan anak. Dengan adanya penjaminan terhadap hak serta kewajiban anak dapat diharapkan mampu meningkatkan kesadaran bersama dalam upaya mencapai perlindungan maksimal bagi anak khususnya.

Mewujudkan kepastian hukum sebagai bentuk perwujudan tujuan hukum itu sendiri adalah suatu hal yang tak sulit dibanding dengan keadilan untuk itu dalam melangsungkan perlindungan anak serta pencegahan perilaku menyimpang terhadap anak sebagai korbannya perlu adanya kepastian hukum dari substansi hukum itu. Aspek yang dibutuhkan dalam upaya perlindungan anak setidaknya ada dua yaitu berkaitan dengan pengaturan hukumnya atau kebijakan perundang-undangan dan selanjutnya aspek dilihat dari pelaksanaan dari aturan tersebut (Nashriana, 2005).

Tanggung jawab orang tua atau keluarga serta peran masyarakat sangat berperan penting serta memberikan pengaruh yang sangat besar terkait upaya perlindungan terhadap anak. Selain itu, peran serta Negara melalui pemerintah dalam melindungi segenap bangsa tak terkecuali anak-anak merupakan poin sentral dalam mewujudkan upaya perlindungan hukum yang memadai. Pelaksanaan kegiatan tersebut harus berkelanjutan dan terarah sesuai sasaran, sehingga dapat menjamin perkembangan serta pertumbuhan dari si anak sendiri baik secara fisik spiritual hingga mental. Pewujudan melalui tindakan ini dapat menambah potensi anak sebagai penerus bangsa yang memiliki jiwa yang tangguh dengan tidak mengurangi rasa nasionalisme serta penjiwaan akhlak yang mulia sebagaimana tertuang dalam Pancasila guna mewujudkan rasa persatuan.

Pembentukan Komisi Penyiaran Indonesia sebagaimana didasari dan diamanatkan dalam Undang-Undang Perlindungan Anak No. 30 Tahun 2014 Jo Undang-Undang No. 23 tahun 2002 telah bermandat untuk melakukan pengawasan serta memantau hal-hal pokok di bidang anak khususnya dalam upaya perlindungan terhadap mereka. Untuk itu, dari sini dapat diinformasikan mengenai wewenang serta tugas dari Komisi ini sebagaimana telah disebutkan tadi sehingga dapat memantau kesesuaian antara produk hukum atau substansinya dengan pelaksanaan di masyarakat. Mengingat itu semua pelaporan hasil dari pelaksanaan pemantauan, nantinya dilakukan dengan bertanggung jawab langsung kepada pemerintah atau pejabat berwenang terkait sebagaimana diamanatkan dalam peraturan perundang-undangan.

Selain perlindungan tersebut di atas Undang-Undang Perlindungan Anak Nomor 35 Tahun 2014 Tentang Perubahan Atas Undang-Undang Nomor 23 Tahun 2002 juga memberikan perlindungan berupa pengenaan sanksi pidana terhadap oknum yang melakukan eksploitasi tersebut. 
Sanksi terhadap oknum yang melakukan eksploitasi anak untuk dijadikan pengemis juga diatur oleh pemerintah melalui ketentuan dalam Pasal 88 Undang-Undang yang sama yaitu Nomor 35 Tahun 2014 Tentang Perubahan Atas Undang-Undang Nomor 23 Tahun 2002 yang mana setiap eksploitasi baik seksual atau tidak terhadap anak guna kepentingan dan keuntungan sendiri maupun untuk orang lain dapat dijatuhi pidana penjara maksimal 10 (sepuluh) tahun hingga denda sebanyak Rp. 200.000.00000. (dua ratus juta rupiah).

\section{SIMPULAN DAN SARAN}

\section{Simpulan}

Dari hasil dan pembahasan yang telah diuraikan di atas, ada beberapa simpulan yang dapat dibuat, yaitu: pertama, pengaturan terhadap anak di bawah umur sebagai pengemis terdapat dan termuat dalam Pasal 2 ayat 1 Undang-Undang Kesejahteraan Anak No. 4 Tahun 1979 yang menjelaskan bahwa hak atas perawatan bimbingan asuhan kesejahteraan serta pembimbingan dengan kasih sayang merupakan hak anak begitu juga terkait pengasuhan tumbuh kembang aanak dalam keluarga sehat yang baik. Pasal ini sudah cukup jelas memaparkan hak setiap anak sehingga apabila dalam realitanya terdapat anak dibawah umur yang menjadi pengemis maka berhak penuntutan atas perlindungannya seperti memperoleh pelayanan kesehatan pendidikan serta kondisi sosial ekonomi yang layak dan wajar sebagaimana termuat dalam Pasal 4 hingga 13 ayat 1 dalam Undang-Undang Perlindungan Anak No. 30 Tahun 2014 Jo UU No. 23 Tahun 2002. Kedua, Perlindungan hukum terhadap anak di bawah umur sebagai pengemis sebagaimana termuat dalam Undang - Undang Perlindungan Anak No. 35 Tahun 2014 Jo Undang-Undang No 23 Tahun 2002 dapat berupa pelayanan kesehatan, sosial ekonomi, serta pendidikan yang memadai. Adapun bentuk perlindungan dalam Undang-Undang tersebut dapat diuraikan yaitu dalam Pasal 44 ayat 1 ayat 3 dan ayat 4 memuat perlindungan terhadap kesehatannya perlindungan berupa pendidikan dapat dilihat dalam Pasal 48 Pasal 50 serta Pasal 53 ayat 1 serta perlindungan sosial pada Pasal 55 dan Pasal 56 yang mengaturnya. Selain perlindungan yang telah disebutkan tersebut pengenaan sanksi terhadap oknum yang melakukan eksploitasi anak untuk dijadikan pengemis juga diatur oleh pemerintah melalui ketentuan dalam Pasal 88 UndangUndang yang sama, yaitu Nomor 35 Tahun 2014 Tentang Perubahan Atas Undang-Undang Nomor 23 Tahun 2002 yang mana setiap eksploitasi baik seksual atau tidak terhadap anak guna kepentingan dan keuntungan sendiri ataupun untuk orang lain dapat dijatuhi pidana penjara maksimal 10 (sepuluh) tahun hingga denda sebanyak Rp. 200.000.000.- (dua ratus juta rupiah).

\section{Saran}

Selain simpulan, ada beberapa saran yang perlu disampaikan berdasarkan hasil dan pembahasan penelitian ini, yaitu: pertama, pemerintah diharapkan dapat membuat aturan yang lebih jelas bagi anak-anak di bawah umur yang terlantar dan menjadi pengemis khususnya memberikan pelatihan dan tempat hidup yang layak agar tidak ada lagi anak dibawah umur yang berprofesi sebagai pengemis. Kedua, pemberian sanksi tegas dan ketat diharapkan dari para Penegak hukum bagi oknum-oknum yang mempekerjakan anak di bawah umur sebagai pengemis serta diharapkan memberikan upaya perlindungan hukum hingga pembinaan terhadap anak di bawah umur yang menjadi pengemis, sehingga dapat mengurangi adanya anak dibawah umur yang menjadi pengemis. Terakhir, peran masyarakat yang diharapkan peduli dengan anak di bawah umur yang menjadi pengemis, sebagai salah satu caranya adalah melaporkan kepada pihak yang berwewenang saat menemukan anak di bawah umur yang menjadi pengemis agar mereka dapat dibina dan mendapatkan kehidupan yang lebih baik lagi.

\section{DAFTAR PUSTAKA}

Hartati, S. (2005). Perkembangan Belajar pada Anak Usia Dini. Jakarta: Depdiknas Dirjen Dikti. International Law Making. (2006). Deklarasi Universal Hak-Hak Asasi Manusia. Jurnal Hukum Internasional, 4(1).

Nashriana. (2005). Perlindungan Hukum bagi Anak di Indonesia. Jakarta: PT Raja Grafindo Persada.

Nihayah, E. S., \& Legowo, M. (2016). Ekploitasi Anak Jalanan (Studi Kasus pada Anak Jalanan di Surabaya). Paradigma, 4(1).

Prints, D. (1997). Hukum Anak Indonesia. Bandung: Citra Aditya Bakti.

Said, M. F. (2018). Perlindungan Hukum terhadap Anak dalam Perspektif Hak Asasi Manusia. JCH 
(Jurnal Cendekia Hukum), 4(1), 141.

Sudrajat, T. (2011). Perlindungan Hukum terhadap Hak Anak sebagai Hak Asasi Manusia dalam Perspektif Sistem Hukum Keluarga di Indonesia. Kanun: Jurnal Ilmu Hukum, 13(54), 111-132.

Sukamti, E. R., \& dkk. (2010). Bermain dan Kreativitas sebagai Fondasi bagi Tumbuh Kembang Anak Usia Dini. Yogyakarta: FIK UNY.

Usman, H., \& Nacorowi, N. D. (2004). Pekerjaan Anak di Indonesia. Jakarta: Grasindo.

Wahid, A., \& Irfan, M. (2001). Perlindungan terhadap Korban Kekerasan Seksual. Bandung: PT. Refika Aditama. 